Reprinted from

Biochimica et Biophysica Acta, 370 (1974) 257-268

(C) Elsevier Scientific Publishing Company, Amsterdam - Printed in The Netherlands

BBA 67349

\title{
ON HUMAN PANCREATIC TRIACYLGLYCEROL LIPASE: ISOLATION AND SOME PROPERTIES
}

\author{
A. VANDERMEERS, M. C. VANDERMEERS-PIRET, J. RATHÉ and J. CHRISTOPHE \\ Department of Biochemistry and Nutrition, University of Brussels Medical School, B-1000 Brussels \\ (Belgium)
}

(Received May 24th, 1974)

\section{SUMMARY}

A single triacylglycerol lipase (EC 3.1.1.3) containing approx. 420 amino acid residues has been purified from human pancreatic juice with a $30 \%$ overall yield. The method involved column chromatography on Sephadex G-25, diethylaminoethylcellulose, carboxymethyl-cellulose and Sephadex G-75. The molecular weight of the enzyme was estimated to be 46000 from the amino acid composition. The purified preparation was incapable of catalyzing a prolonged hydrolysis of tributyrin at $25^{\circ} \mathrm{C}$, because of rapid inactivation. The addition of sodium taurodeoxycholate exerted a protective effect on lipase, an inhibitory action on lipolysis, and a shift of the optimal $\mathrm{pH}$ down to $\mathrm{pH} 7.5$. Increasing the $\mathrm{NaCl}$ concentration enhanced the inhibitory effect of the bile salt, whereas bovine colipase and serum albumin prevented this effect. Only colipase was able to ensure a maximal reaction rate, both in the presence or absence of sodium taurodeoxycholate. Our data indicate that each molecule of human triacylglycerol lipase can easily react with one molecule of bovine colipase, and less easily with two or more molecules.

\section{INTRODUCTION}

The existence of a heat- and acid-stable pancreatic cofactor named colipase has been demonstrated in pig pancreas [1], bovine pancreas [2], and in rat and human pancreatic juice [3]. The main role generally attributed to colipase is to prevent lipase inhibition by high bile salt concentrations. The colipase effect, however, may differ from one species to another: in the presence of bile salts and at $\mathrm{pH} 8$, porcine lipase activity was fully restored by colipase [4], while rat lipase activity was not [3], due to the fact that the optimum $\mathrm{pH}$ was shifted to $\mathrm{pH} 6$.

The precise role of bile salts on lipolysis is also still in dispute.

Owing to these conflicting results and to the importance of intraluminal lipolysis in human physiology and pathology, an attempt was made to purify human pancreatic lipase (triacylglycerol lipase, EC 3.1.1.3) and to study the effects of colipase, bile salts, $\mathrm{NaCl}$ and $\mathrm{pH}$ on its enzymatic activity.

Abbreviations: MOPS, $N$-morpholinopropanesulfonic acid; TAPS, $N$-Tris-(hydroxymethyl)methyl-3-aminopropanesulfonic acid. 
Pure human pancreatic juice devoid of spontaneous proteolytic activity was collected over ice through a drainage tube intubated into the fistula of a patient who had suffered an abdominal injury. Bovine and porcine pancreas were obtained from the slaughterhouse shortly after the death of the animal and kept on ice until processed. Rat pancreas was removed from $150-200 \mathrm{~g}$ animals fed ad libitum on a standard chow.

All the operations of the purification procedures were performed in a cold room using a fraction collector, a peristaltic pump, a conductometer, and an ultraviolet absorptiometer from LKB-producter AB (Stockholm, Sweden). The isolation of human lipase is detailed under the results section. Bovine lipase was prepared by the method of Julien et al. [2], while porcine lipase A was isolated by the method of Verger et al. [5]. Rat lipase was purified as described previously [6].

Bovine colipase was isolated by the acid extraction of pancreas $(600 \mathrm{~g})$, $\left(\mathrm{NH}_{4}\right)_{2} \mathrm{SO}_{4}$ fractionation and ethanol treatment after Erlanson and Borgström [7]. The precipitate was solubilized in water $(200 \mathrm{ml})$ after the elimination of the residual ethanol under vacuum. The solution was subjected to gel filtration on a Sephadex G-25 column $(62 \mathrm{~cm} \times 6.5 \mathrm{~cm})$ and equilibrated with $50 \mathrm{mM}$ Tris- $\mathrm{HCl}$ buffer, $\mathrm{pH}$ 7.6. The filtrate was applied to a column $(30 \mathrm{~cm} \times 3 \mathrm{~cm})$ of DEAE-cellulose equilibrated with $50 \mathrm{mM}$ Tris- $\mathrm{HCl}$ buffer ( $\mathrm{pH} \mathrm{7.6)}$ and eluted with a linear concentration gradient of $\mathrm{NaCl}(0-0.2 \mathrm{M})$ in $300 \mathrm{ml}$ of the initial buffer. A double peak of colipase eluted at a mean conductivity of $3.7 \cdot 10^{-3} \Omega^{-1} \cdot \mathrm{cm}^{-1}$. These two peaks were pooled and concentrated with a rotatory evaporator (Rotavapor Buchi, Switzerland) to a final volume of $10 \mathrm{ml}$. This partial purification was completed by gel filtration on a Sephadex G-75 column $(85 \mathrm{~cm} \times 2 \mathrm{~cm})$ in water.

DEAE-cellulose (microgranular DE 32) is a Whatman product (Maidstone, England). Sephadex G-25, G-75 and G-100 were obtained from Pharmacia (Uppsala, Sweden), and CM-cellulose from Serva (Heidelberg, Germany).

Assay of lipase. Tributyrin was purchased from Fluka (Buchs, Switzerland) and subjected to fractional distillation under vacuum before use. Sodium taurodeoxycholate came from Sigma (St Louis, U.S.A.). Mixed bile salts of bovine origin were a gift from Dr Sarda.

The routine assay of lipase was performed potentiometrically at $\mathrm{pH} 8.0$ and $25^{\circ} \mathrm{C}$ with the Combititrator $3 \mathrm{D}$ from Metrohm AG (Herisau, Switzerland). A tributyrin emulsion $(2.5 \mathrm{ml}$ in $100 \mathrm{ml})$ was stabilized in $1 \mathrm{mM}$ sodium taurodeoxycholate, $0.1 \mathrm{M} \mathrm{NaCl}$ and $2 \mathrm{mM}$ Tris- $\mathrm{HCl}$ buffer $(\mathrm{pH} 8.0$ ). These reagents were stirred continuously with the magnetic device of the titrator. $10 \mathrm{ml}$ of this emulsion and $50 \mathrm{ng}$ (in $100 \mu \mathrm{l}$ water) of bovine colipase were used for each assay. The titrations were performed with $50 \mathrm{mM} \mathrm{NaOH}$. The particular conditions are specified in the legends of the figures. $\mathrm{N}$-Morpholinopropanesulfonic acid (MOPS) and $\mathrm{N}$-Tris-(hydroxymethyl)-methyl-3-aminopropanesulfonic acid (TAPS) were purchased from Serva (Heidelberg, Germany). One lipase unit corresponds to the liberation of one microequivalent butyric acid per minute under the conditions of the assay.

Protein concentration. The protein concentration in crude extracts and in chromatographic eluates was determined by the method of Lowry et al. [8] using crystalline bovine serum albumin as a standard. 
Polyacrylamide disc electrophoresis. The homogeneity of the lipase and colipase preparations was checked by gel electrophoresis. Separating gels contained $7.5 \%$ acrylamide. A $50 \mathrm{mM}$ glycine- $\mathrm{NaOH}$ buffer ( $\mathrm{pH}$ 9.6) was used for protein separation [6].

Amino acid analyses. The amino acid analyses were performed in quadruplicate with a 120 B Beckman Spinco analyser (Palo Alto, U.S.A.). The protein samples were hydrolyzed in $6 \mathrm{M} \mathrm{HCl}$ at $110^{\circ} \mathrm{C}$ in vacuo for 24,48 and $72 \mathrm{~h}$. The individual values were the mean values except for serine and threonine, which were determined by linear extrapolation to zero time. Cystine and methionine were determined after performic oxidation as cysteic acid, and methionine sulfone, respectively [9]. Tryptophan was determined by spectrophotometry [10]. The molecular weight determination of lipase was calculated from the amino acid composition by the Delaage method [11].

\section{RESUlts}

\section{Isolation of human lipase}

The purification procedure is summarized in Table $\mathrm{I} .200 \mathrm{ml}$ of human pancreatic juice were filtered through a column of $6.5 \mathrm{~cm}$ in diameter, containing a $15-\mathrm{cm}$

\section{TABLE I}

\section{FLOW SHEET OF THE PURIFICATION OF HUMAN PANCREATIC LIPASE}

\begin{tabular}{llcc}
\hline Step & $\begin{array}{l}\text { Number of } \\
\text { lipase units } \\
\left(\times 10^{-3}\right)\end{array}$ & $\begin{array}{l}\text { Specific } \\
\text { activity }\end{array}$ & $\begin{array}{l}\text { Yield } \\
(\%)\end{array}$ \\
\hline 1. Pancreatic juice & 600 & 300 & 100 \\
2. DEAE-cellulose chromatography & 300 & 1800 & 50 \\
3. CM-cellulose chromatography & 198 & 7200 & 33 \\
4. Sephadex G-75 filtration & 180 & 9000 & 30
\end{tabular}

- The activity of lipase, in the presence of an excess of colipase, was determined as indicated under Materials and Methods.

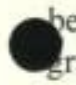

ed of DEAE-cellulose topped by a 75-cm bed of Sephadex G-25. Both chromatoraphic supports were equilibrated with $13 \mathrm{mM}$ Tris- $\mathrm{HCl}$ buffer at $\mathrm{pH}$ 8.2. Elution was performed with the same buffer enriched with $0.5 \mathrm{M} \mathrm{NaCl}$. The desalted lipase, together with the other non-retarded cationic proteins, was eluted in front, in a volume of $370 \mathrm{ml}$. No lipolytic activity was found in the eluate collected at higher ionic strength. The cationic lipase fraction was adjusted to $\mathrm{pH} 6.3$ by the addition of $1 \mathrm{M} \mathrm{HCl}$ with gentle stirring. This solution was loaded on a CM-cellulose column $(15 \mathrm{~cm} \times 2 \mathrm{~cm})$ equilibrated with $10 \mathrm{mM}$ Tris-succinate buffer $(\mathrm{pH} 6.3)$. The proteins were eluted with a linear $0-0.3 \mathrm{M}$ gradient of $\mathrm{NaCl}$ in $10 \mathrm{mM}$ Tris-succinate buffer ( $\mathrm{pH}$ 6.3). The gradient was obtained with two chambers of $200 \mathrm{ml}$ each. Lipase activity was located in a single peak corresponding to a conductivity of $3.1 \cdot 10^{-3}$ $\Omega^{-1} \cdot \mathrm{cm}^{-1}$.

The volume of the fractions of interest $(85 \mathrm{ml})$ was reduced with dry Sephadex G-25 [12] to $9 \mathrm{ml}$ by three successive concentration steps. The final supernatant was 
submitted to gel filtration through a column of Sephadex G-75 $(85 \mathrm{~cm} \times 2 \mathrm{~cm})$. As shown in Fig. 1, the lipase specific activity was almost constant in the first fractions of a peak eluted after 1.6 void volume. Only the last portion of the peak was increasingly contaminated. The seven best fractions were pooled and dialyzed against water. This final solution was divided into $5-\mathrm{ml}$ aliquots and stored at $-40{ }^{\circ} \mathrm{C}$ (The preparation proved to be labile at $0^{\circ} \mathrm{C}$ even in the presence of $1 \mathrm{mM}$ diisopropylfluorophosphate: approximate half-life, 2 days). Polyacrylamide gel electrophoresis of the purified human lipase revealed only one band (Fig. 1).

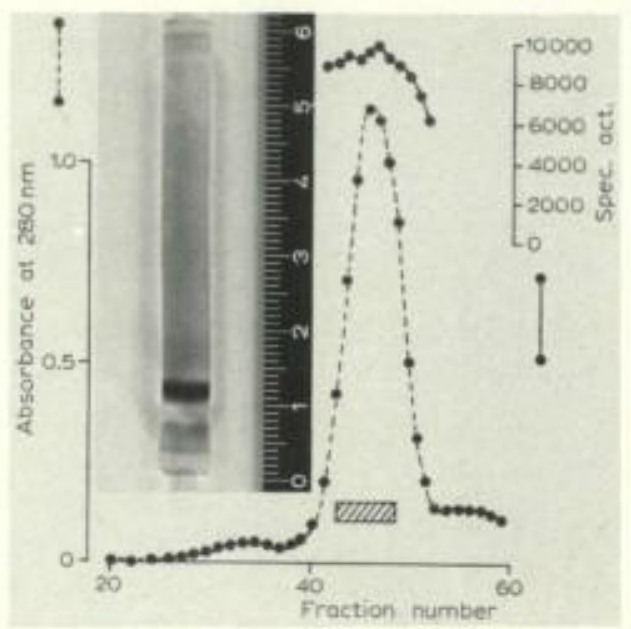

Fig. 1. Filtration of human lipase through Sephadex G-75 as a last step of purification. The Sephadex G-75 column $(85 \mathrm{~cm} \times 2 \mathrm{~cm})$ was equilibrated and eluted with distilled water. -- absorbance at $280 \mathrm{~nm}$; - specific activity in $\mu$ moles of butyric acid liberated per min at $25^{\circ} \mathrm{C}$ per mg protein. The seven fractions corresponding to the hatched area were pooled, dialyzed against water, and kept frozen at $-40^{\circ} \mathrm{C}$. An aliquot was submitted to disc electrophoresis under the conditions described in Materials and Methods.

The human lipase sample so obtained was essentially free of colipase since its activity in the presence of $5 \mathrm{mM}$ taurodeoxycholate was very low. In fact a single gel filtration of crude human pancreatic juice on Sephadex G-100 was already very effective in separating lipase from colipase. The possibility that traces of colipase remained bound to purified human lipase was tested in the following manner. An aliquot of the lipase preparation was acidified at $\mathrm{pH} 2$ in order to destroy the enzyme activity and then neutralized again. The ability of this sample to restore rat lipase [6] activity in the presence of $5 \mathrm{mM}$ taurodeoxycholate was tested at $\mathrm{pH} 7.0$. This ability was compared with that of a purified bovine colipase standard. The negligible colipase effect found associated with human lipase corresponded at most to a contamination by $0.35 \%(w / w)$ colipase.

\section{Amino acid composition and molecular weight of human lipase}

Table II compares human lipase with three other lipases: the rat enzyme isolated in our laboratory some years ago [6], and the two porcine enzymes studied by Verger et al. [5]. The four amino acid compositions are very similar, but human 
TABLE II

COMPARATIVE AMINO ACID COMPOSITION OF HUMAN, RAT, AND PIG PANCREATIC LIPASES

Number of residues per mole: nearest integers.

\begin{tabular}{|c|c|c|c|c|}
\hline \multirow{2}{*}{$\begin{array}{l}\text { Amino acid } \\
\text { residue }\end{array}$} & \multirow[t]{2}{*}{ Human } & \multirow[t]{2}{*}{ Rat $^{*}$} & \multicolumn{2}{|l|}{ Porcine ${ }^{* *}$} \\
\hline & & & A & B \\
\hline Asx & 55 & 57 & 56 & 56 \\
\hline Thr & 25 & 25 & 26 & 25 \\
\hline Ser & 35 & 32 & 28 & 28 \\
\hline Pro & 20 & 18 & 25 & 24 \\
\hline Glx & 33 & 33 & 38 & 38 \\
\hline Gly & 41 & 40 & 39 & 37 \\
\hline Ala & 24 & 23 & 20 & 20 \\
\hline Val & 30 & 34 & 34 & 33 \\
\hline Cys (half) & 14 & 11 & 13 & 13 \\
\hline Met & 4 & 7 & $3-4$ & $3-4$ \\
\hline Ile & 20 & 23 & 28 & 24 \\
\hline Leu & 24 & 28 & 29 & 29 \\
\hline Tyr & 13 & 14 & 15 & 15 \\
\hline Phe & 24 & 23 & 22 & 23 \\
\hline Lys & 23 & 25 & 21 & 22 \\
\hline His & 11 & 11 & 10 & 10 \\
\hline Arg & 15 & 18 & 20 & 20 \\
\hline Trp & 8 & 8 & 7 & 7 \\
\hline Total & 419 & 430 & $434 \quad 435$ & $427-428$ \\
\hline $\begin{array}{l}\text { Molecular } \\
\text { weight }{ }^{* * *}\end{array}$ & 46000 & 48000 & 48000 & 48000 \\
\hline
\end{tabular}

- From Vandermeers and Christophe [6].

* From Verger et al. [5].

... Calculated by the method of Delaage [11].

lipase was somewhat richer in serine and poorer in isoleucin and arginine. The molecular weight calculated by the Delaage method [11] was $+\leqslant 00$ for the human enzyme.

Lipolysis in the absence of colipase and bile salts

Fig. 2 (left) shows a kinetic graph (curve a) obtained with pure lipase at $\mathrm{pH} 8$ in the concomitant absence of bile salt and colipase. The main feature of this titration curve is a lack of linearity, provoking a great inaccuracy in the measurement of the initial velocity. After only $2 \mathrm{~min}$, the reaction rate had decreased by more than $90 \%$, indicating the rapid inactivation of pure lipase at $25^{\circ} \mathrm{C}$. Such an inactivation was not encountered with a crude colipase-free preparation of lipase obtained after a simple filtration of human pancreatic juice through a Sephadex G-100 column.

Effect of sodium taurodeoxycholate on lipolysis

Sodium taurodeoxycholate at a $5 \mathrm{mM}$ concentration exerted two distinct effects when added to a tributyrin-purified human lipase system, in $10 \mathrm{mM} \mathrm{NaCl}$ at $\mathrm{pH}$ 8. The first effect was to ensure linear kinetics. This is interpreted as resulting 


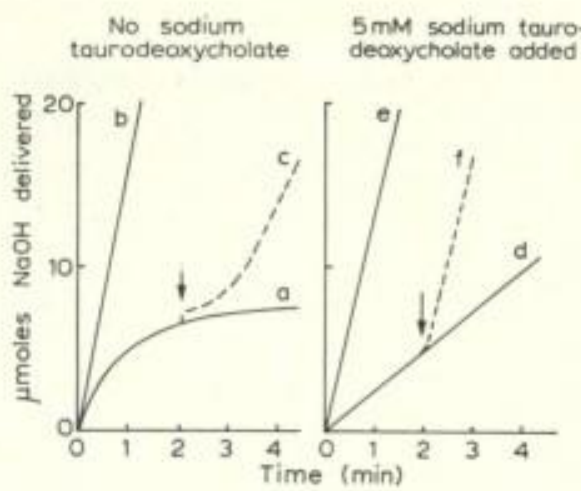

Fig. 2, Reaction curves obtained by the continuous titration of liberated butyric acid. The tributyrinhuman lipase system was tested in $2 \mathrm{mM}$ Tris- $\mathrm{HCl}$ buffer $(\mathrm{pH} 8.0)$ and $10 \mathrm{mM} \mathrm{NaCl}$, in the absence of sodium taurodeoxycholate (left: $\mathrm{a}, \mathrm{b}$ and $\mathrm{c}$ ); and in the presence of $5 \mathrm{mM}$ sodium taurodeoxycholate (right: d, e and f). Colipase in a saturating amount ( $50 \mu \mathrm{g} / \mu \mathrm{g}$ lipase) was absent (curves a and $\mathrm{d}$, present at zero time (curves b and e) or added only after a 2 -min reaction time (curves $\mathrm{c}$ and $\mathrm{f}$ : $\downarrow--)$.

from a greater stability of lipase in the presence of the bile salt (Fig. 2, curve d as compared to curve a), since a delayed addition of colipase (curve $f$ ) allowed full recovery of lipase activity (curve e), contrary to what was observed without bile salt (curve c). The second effect of $5 \mathrm{mM}$ taurodeoxycholate was a marked decrease of the initial velocity in the absence of colipase. This inhibitory effect was maximal and practically total when the $\mathrm{NaCl}$ concentration was $100 \mathrm{mM}$, i.e. under our standard assay conditions (Fig. 3). The influence of increasing taurodeoxycholate concentrations was further documented with a moderate $(25 \mathrm{mM})$ concentration of $\mathrm{NaCl}$, at $\mathrm{pH} 8.2$. At intermediary $(1.25-2.50 \mathrm{mM})$ taurodeoxycholate concentrations, a slight stimulation was observed, probably by stabilization rather than by real activation. On the other hand, the high sodium taurodeoxycholate concentration (5 mM)

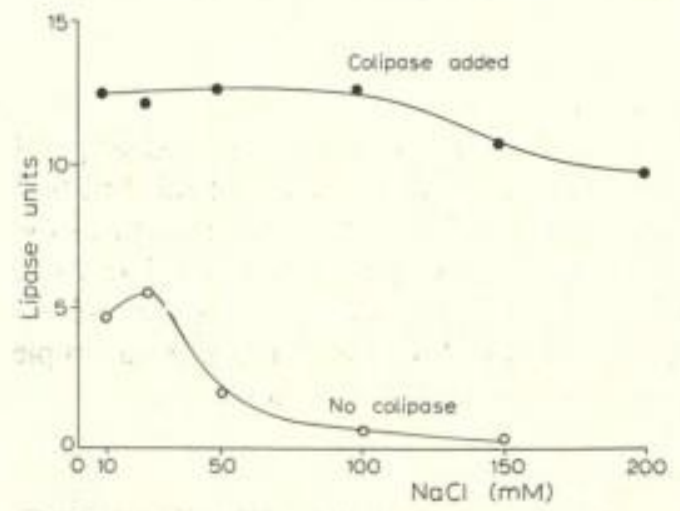

Fig. 3. Effect of $\mathrm{NaCl}$ concentration on the activity of the human lipase-bile salt system. The assays were conducted for $3 \mathrm{~min}$ in $2 \mathrm{mM}$ Tris- $\mathrm{HCl}$ buffer $(\mathrm{pH} 8.0)$ and $5 \mathrm{mM}$ sodium taurodeoxycholate, in the presence (-) or absence $(\mathrm{O}-\mathrm{O})$ of colipase in a saturating amount (50 $\mu \mathrm{g} / \mu \mathrm{g}$ lipase). 


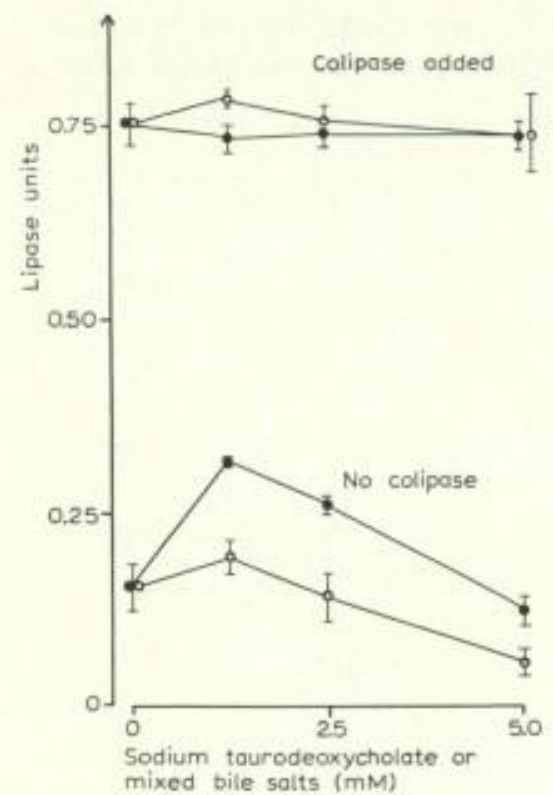

Fig. 4. Human lipase activities related to increasing concentrations of sodium taurodeoxycholate $(\mathrm{O}-\mathrm{O})$ or mixed bile salts (-) were measured after $3 \mathrm{~min}$ in $2 \mathrm{mM}$ Tris- $\mathrm{HCl}(\mathrm{pH} 8.2)$ and $25 \mathrm{mM} \mathrm{NaCl}$ in the presence or absence of colipase in a saturating amount ( $50 \mathrm{\mu g} / \mathrm{\mu g}$ lipase). Mean values \pm S.E. of $4-5$ determinations.

was again inhibitory. These phenomena (Fig. 4) were not specific for taurodeoxycholate. Similar observations were made with a mixed bile salt preparation of bovine origin.

\section{Effect of $\mathrm{NaCl}$}

Fig. 3 shows that increasing the $\mathrm{NaCl}$ concentration from 25 to $150 \mathrm{mM}$ in the absence of colipase and in the presence of $5 \mathrm{mM}$ taurodeoxycholate almost completely inhibited the lipase activity. When colipase was present in addition to the bile salt, only a slight inhibition by $\mathrm{NaCl}$ was observed at concentrations higher than $100 \mathrm{mM}$.

\section{Effect of pure bovine colipase, crude bovine colipase and albumin}

Four distinct favourable effects can be assigned to pure bovine colipase; the first three in the absence, and the last in the presence of sodium taurodeoxycholate. Without taurodeoxycholate, colipase (1) protected lipase from gradual inactivation (Fig. 2, curve b versus curve a); (2) partially restored the activity which disappeared during the 2-min preincubation with tributyrin alone (Fig. 2, curve c), and (3) enhanced the initial reaction rate of tributyrin hydrolysis (Fig. 2, curves a and b). In the presence of taurodeoxycholate, colipase, when added at zero time, prevented lipase inhibition by taurodeoxycholate (Fig. 2, curve e), and when added after a delay of 2 min completely reversed the inhibition due to taurodeoxycholate (Fig. 2, curve f). The response to increasing doses of colipase appeared to be linear when the 
ratio of colipase versus lipase did not exceed 0.5 . For a molar ratio of 2 , a plateau was approached, but further increasing the colipase concentration still resulted in slightly greater activity (Fig. 5).

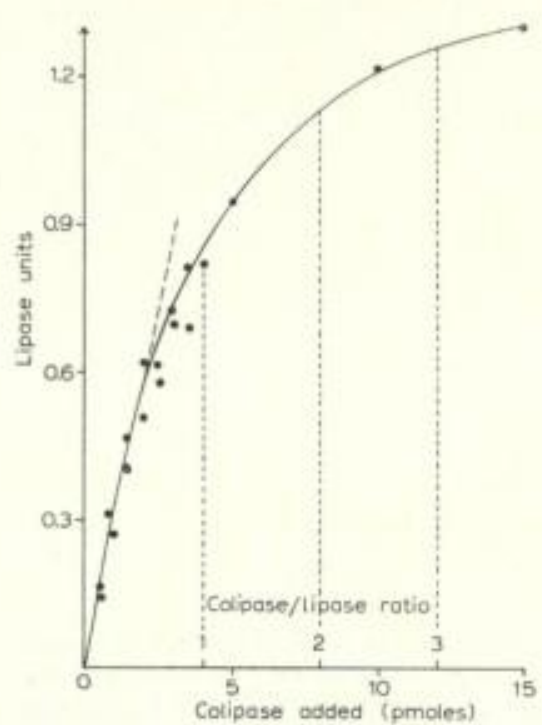

Fig. 5. Activation of human lipase by increasing amounts of bovine colipase in the presence of $5 \mathrm{mM}$ sodium taurodeoxycholate. The assays were conducted for $3 \mathrm{~min}$ in $2 \mathrm{mM}$ Tris- $\mathrm{HCl}(\mathrm{pH} 8.0)$ and $100 \mathrm{mM} \mathrm{NaCl}$ with 4 pmoles of lipase.

When compared to pure bovine colipase, a crude preparation consisting of the supernatant of a pancreas homogenate heated to $75^{\circ} \mathrm{C}$ for $30 \mathrm{~min}$, or a commercial bovine serum albumin, only partially reversed the inhibitory effect of taurodeoxycholate (Fig. 6).

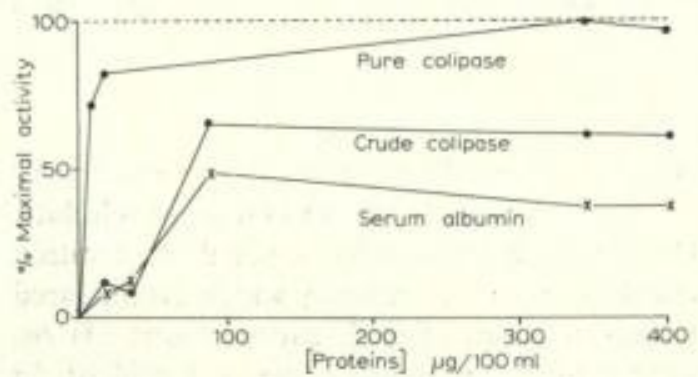

Fig. 6. Comparison of the activation of human lipase with increasing concentrations of purified bovine colipase, crude bovine colipase and bovine serum albumin. The assays were conducted for $3 \mathrm{~min}$ in $2 \mathrm{mM}$ Tris- $\mathrm{HCl}(\mathrm{pH} 6.0$ ) and $100 \mathrm{mM} \mathrm{NaCl}$ with $0.2 \mathrm{ng}$ of human lipase in the presence of $5 \mathrm{mM}$ sodium taurodeoxycholate. The data were expressed as a percentage of the maximal value obtained with colipase. 


\section{Effect of $p H$}

Fig. 7 represents the pH-activity curves of human lipase under three conditions: with colipase ( $50 \mu \mathrm{g}$ colipase $/ \mu \mathrm{g}$ lipase, i.e. a 250:1 molar ratio), with $5 \mathrm{mM}$ taurodeoxycholate, and with colipase and taurodeoxycholate in combination. Linear kinetic graphs were obtained in all instances. A tapering of kinetics similar to that observed with the omission of colipase and bile salts was never encountered.
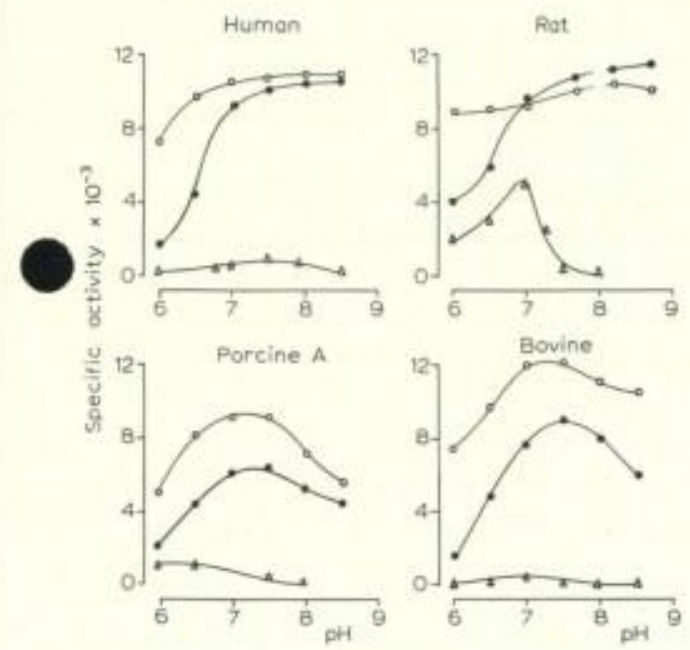

Fig. 7. pH-dependent profiles of the activity of four colipase-free lipases in the presence of $5 \mathrm{mM}$ sodium taurodeoxycholate $(\Delta-\Delta)$, and of the same lipases saturated with bovine colipase (50 $\mu \mathrm{g}$ colipase $/ \mu \mathrm{g}$ lipase), both in the presence $(5 \mathrm{mM}:-)$ or absence $(\mathrm{O}-\mathrm{O})$ of sodium taurodeoxycholate, The mixed buffer consisted of $6 \mathrm{mM}$ acetic acid, $4.5 \mathrm{mM}$ maleic acid, $5 \mathrm{mM}$ MOPS, $5 \mathrm{mM}$ TAPS, and $5 \mathrm{mM}$ glycine in $100 \mathrm{mM} \mathrm{NaCl}$, and was adjusted to the desired value by the use of $1 \mathrm{M}$ $\mathrm{NaOH}$. The origin of the four lipases is described under Materials and Methods.

Human lipase was always most active when colipase alone was added to the incubation mixture. The velocity was a maximum at $\mathrm{pH} 8.5$, but did not vary much over the $\mathrm{pH}$ range from $\mathrm{pH} 7.5$ to 8.5 . The addition of $5 \mathrm{mM}$ taurodeoxycholate together with colipase did not appreciably decrease the reaction rate in the $\mathrm{pH}$ range $7.0-8.5$, but exerted an increasingly inhibitory effect towards acidic $\mathrm{pH}$ values. In the presence of $5 \mathrm{mM}$ taurodeoxycholate only, the $\mathrm{pH}$-activity curve showed a marked inhibition in the whole $\mathrm{pH}$ range. Moreover, the optimum $\mathrm{pH}$ was 7.5 , i.e. it had slightly shifted towards a more acidic $\mathrm{pH}$ range.

This effect of $5 \mathrm{mM}$ taurodeoxycholate on human lipase activity was comparable to that obtained with rat, porcine A and bovine enzymes (Fig. 7). In each case, taurodeoxycholate was responsible for a strong inhibition accompanied by a shift of the $\mathrm{pH}$ optimum towards the acidic range. The addition of bovine colipase restored the activity of all lipases tested to almost maximal values, and increased the optimal $\mathrm{pH}$ to the alkaline range. 


\section{DISCUSSION}

Purification, calculated molecular weight and amino acid composition of human lipase

A great deal of lipase activity was lost during the first chromatographic step yielding the cationic proteins. However, no lipolytic activity was found in the eluate collected at a higher ionic strength from DEAE-cellulose, i.e. in the anionic proteins. In other terms we found no traces of the existence of a second human pancreatic lipase similar to that described by Bradshaw and Rutter [13]. Since all our assays were performed in the presence of an excess of bovine colipase, the most likely explanation for the low yield of the first purification step is the occurrence of some proteolysis during the chromatographic elution in spite of the fact that the starting juice was devoid of spontaneous tryptic and chymotryptic activities.

The molecular weight of 46000 measured by the Delaage method [11] agrees well with that of 48000 found by the same method for rat [6] and porcine [5] lipases (Table II). However, lower molecular weights which ranged from 35000 to 45000 for porcine lipases [5] and from 32000 to 43000 for rat lipase [6, 14] have been estimated by gel filtration on Sephadex. This discrepancy is surprising because an overevaluation would be expected for the values obtained from gel filtration experiments, owing to the possible lipid contamination of lipase molecules [6]. This is why we thought previously that the value of 43000 found in our laboratory for the rat enzyme had to be reduced to 37000 after a tentative evaluation of the contaminating lipids.

The amino acid composition of human lipase resembles that of rat and porcine lipases, although the human enzyme was somewhat richer in serine and poorer in isoleucine and arginine. In fact, the major discrepancy in the four amino acid compositions (Table II) was observed for the rat enzyme which seems relatively rich in methionine residues.

\section{Enzymatic activity of human lipase}

Tributyrin was preferred as a substrate for the study of lipase activity because the ratio of the rate of tributyrin hydrolysis versus triolein hydrolysis was as high as 12 when measured at $\mathrm{pH} 8$ in $50 \mathrm{mM} \mathrm{NaCl}$ and $1 \mathrm{mM}$ taurodeoxycholate as emulsifier. Nevertheless with triolein as a substrate the relationships were rather similar to those observed with tributyrin i.e. supramicellar bile salt concentrations were inhibitory and this inhibition was reversed by colipase. However, when $5 \mathrm{mM}$ taurodeoxycholate and colipase were present the kinetic reaction graphs traced at $\mathrm{pH} 8.0$ exhibited a lag period which was much more important with triolein than with tributyrin.

The hydrolysis of a tributyrin emulsion by pure human lipase was possible in the presence of $100 \mathrm{mM} \mathrm{NaCl}$ and required neither bile salts nor emulsifier. However, the time study of hydrolysis revealed a rapid loss of activity accompanied by a partially irreversible denaturation (Fig. 2). Most probably, this denaturation was due to the unfolding of some lipase molecules at the oil-water interface [15].

Three major types of effects were observed upon the addition of reagents interacting with the lipase-tributyrin system: protection of lipase against denaturation, inhibition of lipase activity, and reversal of lipase inhibition.

The first effect was observed not only with colipase and sodium taurodeoxy- 
cholate (Fig. 2) but also with the undefined contaminating proteins present in a crude lipase fraction of human pancreatic juice (data not shown). It is tempting to ascribe this protective effect to a common mechanism. Brockerhoff [16] has suggested that taurocholate, colipase and albumin are directly adsorbed onto the lipid phase, creating a layer capable of protecting lipase on the substrate emulsion. A similar mechanism was proposed by Schoor and Melius [17] for taurocholate. This would explain why colipase, in the absence of bile salts, was unable to activate partially purified lipases from rat and human pancreas [18] (i.e. preparations contaminated with other proteins), while the same colipase was reported in more recent publications to stimulate pure bovine [2], porcine [4] and rat [19] enzymes.

The second effect was an inhibition of human lipase by micellar concentrations of taurodeoxycholate accompanied by a shift of the optimal $\mathrm{pH}$ down to around $\mathrm{pH}$ 7.5. The consequences of high bile salt concentrations have been recognized for some time for rat [3] and porcine [4] lipase. The present study has confirmed and extended these observations to human and bovine lipase (Fig. 7). Increasing $\mathrm{NaCl}$ concentration from 10 to $100 \mathrm{mM}$ gradually enhanced the inhibitory effect of $5 \mathrm{mM}$ taurodeoxycholate on human lipase (Fig. 3). This observation confirms that the inhibitory effect of bile salts is related to their critical micellar concentration [4, 19].

The third effect was the colipase-induced reversal of the inhibition of human lipase caused by sodium taurodeoxycholate. This probably corresponds to the main physiological effect of colipase in the lumen of the small intestine. This has been observed with all lipases investigated thus far. Our comparative study (Fig. 7) of the effect of bovine colipase on the activity of human, rat, porcine A and bovine lipases gave similar results. The addition of colipase strongly reduced the inhibition of the four lipase preparations. It abolished the shift of the optimal pH caused by $5 \mathrm{mM}$ sodium taurodeoxycholate. The latter observation is in agreement with a recent report on porcine lipase [4], but disagrees with other data concerning rat lipase [3, 19].

At the constant $\mathrm{pH} 8.0$, we found that the restoration of human lipase activity by colipase in the presence of $5 \mathrm{mM}$ sodium taurodeoxycholate was unaffected by increasing the $\mathrm{NaCl}$ concentration from 10 to $100 \mathrm{mM}$ (Fig. 3). This contrasts with the narrow $100-150 \mathrm{mM}$ concentration range of $\mathrm{NaCl}$ required for optimal activity when rat lipase is incubated in the presence of colipase and $4 \mathrm{mM}$ sodium taurodeoxycholate [19].

The specificity of colipase as a lipase cofactor was examined by comparing the antagonistic effect of colipase on sodium taurodeoxycholate inhibition with the same effect exerted by bovine serum albumin, and the soluble material obtained after heating bovine pancreas at $75^{\circ} \mathrm{C}$ for $30 \mathrm{~min}$. Our results (Fig. 6) indicate that some reactivation was possible when using the crude heat-stable pancreatic supernatant or albumin. However, neither the enhancement of lipase activity with increasing doses of proteins, nor the final plateau reached in both cases, were comparable to the corresponding values recorded with pure colipase (Fig. 6).

The lower plateau obtained with the heat-stable material from pancreas casts some doubt on the validity of a quantitative colipase assay. Further investigation will be necessary to test if exogenous proteins are able to influence the response of lipase activity to increasing colipase concentrations in crude biological materials such as pancreatic juice or tissue homogenates. This verification would be especially impor- 
tant in the linear portion of the curve which corresponds to a ratio of colipase versus lipase inferior to 1, the region theoretically useful in colipase assays.

Our curve in Fig. 5 suggests that one molecule of human lipase can easily react with one, and less easily with two or more molecules of bovine colipase, in the presence of $5 \mathrm{mM}$ sodium taurodeoxycholate. This observation is in keeping with recent data [19]. Desnuelle et al. [20] have reported that one molecule of colipase combines with one or two micelles of bile salt at supra-critical micellar concentrations of these salts. This association can further combine with one molecule of porcine lipase, forming a ternary complex where biliary salts are no longer capable of inhibiting the active center of the enzyme.

\section{ACKNOWLEDGMENTS}

The authors wish to thank Drs A. Delcourt and R. van der Hoeden (Institut Médico-Chirurgical d'Ixelles, Brussels, Belgium) for the valuable sample of human pancreatic juice and Dr L. Sarda (Marseilles, France) for the gift of mixed bile salts. This investigation was supported by grant No. 20,403 from the Fonds de la Recherche Scientifique Médicale (Bellgium).

\section{REFERENCES}

1 Baskys, B., Klein, E. and Lever, W. P. (1963) Arch. Biochem. Biophys. 102, 201-209

2 Julien, R., Canioni, P., Rathelot, J., Sarda, L. and Plummer, Jr, T. H. (1972) Biochim. Biophys. Acta 280, 215-224

3 Borgström, B. and Erlanson, C. (1971) Biochim. Biophys. Acta 242, 509-513

4 Maylié, M. F., Charles, M., Astier, M. and Desnuelle, P. (1973) Biochem. Biophys. Res. Commun. 52, 291-297

5 Verger, R., de Haas, G. H., Sarda, L. and Desnuelle, P. (1969) Biochim. Biophys. Acta 188, 272-282

6 Vandermeers, A. and Christophe, J. (1968) Biochim. Biophys. Acta 154, 110-129

7 Erlanson, C. and Borgström, B. (1972) Biochim. Biophys. Acta 271, 400-412

8 Lowry, O. H., Rosebrough, N. J., Farr, A. L. and Randall, R. J. (1951) J. Biol. Chem. 193, 265275

9 Moore, S. (1963) J. Biol. Chem. 238, 235-237

10 Beaven, G. H. and Holiday, E. R. (1952) Adv. Protein Chem. 7, 319-386

11 Delaage, M. (1968) Biochim. Biophys. Acta 168, 573-575

12 Flodin, P., Gelotte, B. and Porath, J. (1960) Nature 188, $493-494$

13 Bradshaw, W. S. and Rutter, W. J. (1972) Biochemistry 11, 1517-1528

14 Gidez, L. I. (1968) J. Lipid Res. 9, 794-798

15 Brockerhoff, H. (1971) J. Biol. Chem. 246, 5828-5831

16 Brockerhoff, H. (1973) Chem. Phys. Lipids 10, 215-222

17 Schoor, W. P. and Melius, P. (1970) Biochim. Biophys. Acta 212, 173-175

18 Morgan, R. G. H. and Hoffman, N. E. (1971) Biochim. Biophys. Acta 248, 143-148

19 Borgström, B. and Erlanson, C. (1973) Eur. J. Biochem. 37, 60-68

20 Desnuelle, P., Charles, M., Sari, H. and Erlanson, C. (1973) Forum de Recherches de la Société Française de Gastro-Entérologie, Strasbourg 